\title{
A critical approach to soft power: Grasping contemporary Turkey's influence in the world
}

Gabrielle Angey-Sentuc and Jérémie Molho

\section{Q OpenEdition \\ 1 Journals}

\section{Electronic version}

URL: http://journals.openedition.org/ejts/5287

DOI: 10.4000/ejts.5287

ISSN: $1773-0546$

Publisher

EJTS

\section{Electronic reference}

Gabrielle Angey-Sentuc and Jérémie Molho, «A critical approach to soft power: Grasping contemporary Turkey's influence in the world », European Journal of Turkish Studies [Online], 21 | 2015, Online since 17 March 2016, connection on 16 February 2020. URL : http://journals.openedition.org/ ejts/5287 ; DOI : 10.4000/ejts.5287

This text was automatically generated on 16 February 2020.

(C) Some rights reserved / Creative Commons license 


\title{
A critical approach to soft power: Grasping contemporary Turkey's influence in the world
}

\author{
Gabrielle Angey-Sentuc and Jérémie Molho
}

We would like to thank the French Institute of Anatolian Studies for providing the financial and material support for this project in addition to the ANR "Trans-acting Matters: Areas and Eras of a (Post-)Ottoman Globalization". We would also like to extend our thanks to all the project participants who contributed to the reflections presented in this introduction. We also thank the editorial board of the European Journal of Turkish Studies, and especially Marc Aymes.

\section{Thinking Turkish influence in the midst of a dramatic political shift}

1 On 5 April 2015, Joseph Nye, the scholar who first coined the term "soft power", was quoted in an article published in Today's Zaman asserting that Turkish soft power had declined over the past few years. According to Nye, as a result Turkey would subsequently have "less soft power, less democracy". ${ }^{1}$ During the 2000s, the concept of soft power became a popular term applied to the perceived rise in Turkey's global and regional influence. The article in Today's Zaman not only reminds us of the dramatic internal and external shifts that have affected Turkey since 2013, but also raises questions concerning the capacity of the concept to characterise Turkey's influence beyond its borders.

2 This special issue of Beyond Soft Power: Stakes and configurations of the influence of contemporary Turkey' is the result of a research project initiated in early 2013 at the French Institute of Anatolian Studies in order to question the concept of soft power and develop new perspectives and empirically based research critically examining Turkey's presence abroad. ${ }^{2}$ At the time of the project's initiation, the regional and domestic configurations of Turkey differed absolutely from the current crisis context. Turkey's influence in the Balkans, the Middle East, Central Asia and even in Africa, had been 
progressively expanding for several decades, a trend also perceptible in Ankara's increasing involvement in international organisations. The Arab Spring led to a conducive environment for the idealisation of the so-called "Turkish model" of governance. Meanwhile, Davutoğlu's "zero problem with the neighbours" policy (Davutoğlu 2001) had become well known and was represented as a success. Turkey's substantial development and growth stood in marked contrast to the economic crisis in EU countries. Turkey's presence in the media and the broadcasting of Turkish TV shows abroad, particularly in neighbouring countries with shared cultural affinities, was perceived as evidence of the country's rising cultural attractiveness. The Turkish government itself emphasised the growth of its cultural and diplomatic influence through a self-promoting soft power and Turkish model discourse. However, regional and domestic shifts occurring in the past few years have raised serious questions concerning the legitimacy and authority of this discursive framework. Ankara's ability to affect neighbouring actors has been limited by a number of internal and external political episodes that have shed light on Turkey's regional and international presence. Turkey's military involvement in the Syrian and Iraq war from summer 2015, the declining security situation on its domestic territory, including the bomb attacks in Suruç (20 July 2015), Ankara (10 October 2015; 13 March 2016), and Istanbul (12 January 2016), the reactivation of the war against the Kurdistan Workers' Party (PKK) in SouthEast Turkey following the end of the peace process, the rising authoritarian tendencies of Erdoğan's regime, and the judicial war against the Gülen movement, have cast serious doubts on Turkey's position. ${ }^{3}$ Consequently analysts have stopped glorifying Turkey as a source of inspiration for the region.

3 The shifting political context confirmed our initial intuitions, underlining the inadequacy of the concept of soft power for apprehending the complex dynamics and stakes of Turkey's commitment beyond its borders. Consequently, through grounded researches on contemporary Turkey's influence, this special issue makes a necessary contribution by theoretically questioning and redefining the value of the concept of soft power. Our aim is to go "beyond" the use of soft power as an analytical tool by addressing its limitations and suggesting alternative approaches to analysing the transnational and international dynamics of a country.

\section{The soft power concept: a category of analysis or a category of practice?}

In order to clarify the issues in the debate on soft power, we shall review the genealogy of this concept by introducing Nye's initial theory and considering its subsequent evolution and spread around the world. From an American-centered perspective to the analysis of the rise of emerging powers, and from a state-centered theory to the emphasis on the role of non-state actors, the various uses of the notion of soft power have demonstrated its malleability. Furthermore, in addition to its function as an analytical device, the concept is often coined as a rhetorical argument in support of foreign policy consultancy. 


\section{A genealogy of the soft power concept}

5 At first glance, soft power seems to be a relatively simple concept to comprehend, its reach often extending far beyond the academic field. Usually defined in opposition to hard power (physical and economic coercion), its origins are easy to trace to the Princeton and Harvard-educated political scientist Joseph Nye, the American scholar responsible for coining the term. Since its introduction, Nye has continuously updated and promoted the concept and theory. He has been a Harvard faculty member since 1964, and served as the Dean of the John F. Kennedy School of Government from 1995 to 2004. He held several positions in Washington, including Deputy to the Undersecretary of State for Security Assistance and Science and Technology in the Carter Administration from 1977 to 1979, and Assistant Secretary of Defence for International Security in the Clinton Administration between 1994 and 1995. He is also the head of the Northern American Chair of the Trilateral Commission, a private organisation gathering together influential intellectuals on contemporary politics. Soft power evolved over time as Nye theoretically developed the concept, and as it was adopted to meet the needs of various interests or places.

6 A genealogy of Nye's theory shows that it evolved in correlation with the global geopolitical context and in reaction to its critiques. In 1990, Joseph Nye introduced the concept of soft power in the book Bound to Lead: The Changing Nature of American Power (Nye 1990a), and in an article published in the same year in the journal Foreign Policy (Nye 1990b). At that time, the main goal of soft power analysis was to show that America was not a declining power ${ }^{4}$ and, in Nye's view, would retain its position as the world's leading superpower. Instead of retrenching behind its frontiers, he argued that the USA had to maintain an ambitious foreign policy program through the use of "soft power". These initial works defined soft power as part of a generalised strategy of the state in an increasingly interdependent world:

Soft cooptive power is just as important as hard command power. If a State can make its power seem legitimate in the eyes of others, it will encounter less resistance to its wishes. If its culture and ideology are attractive, others will more willingly follow. If it can establish international norms consistent with its society, it is less likely to have to change. If it can support institutions that make other states wish to channel or limit their activities in ways the dominant state prefers, it may be spared the costly exercise of coercive or hard power. (Nye 1990a: 167)

7 Nye insists on the importance of soft power for states in the post-Cold War interconnected world: gaining legitimacy for international actions, enhancing a state's capacity to form international coalitions, avoiding being subject to the influence of others, and preventing military confrontations. A more elaborate theory appeared in his following works, particularly in his book Soft Power: the Means to Success in World Politics (2004b), in which an in-depth analysis of the three sources of a country's soft power was developed: "Its culture (in places where it is attractive to others), its political values (when it lives up to them at home and abroad), and its foreign policies (when they are seen as legitimate and having moral authority)" (Ibid:: 11). Finally, in Powers to Lead: Soft, Hard and Smart (2008) and The future of Power (2011), Nye introduced the term "smart power" to refer to the complementarity that exists between hard and soft power. Through this new concept, Nye advocated a foreign policy that combines military presence with investments in alliances and partnerships with a wide variety of external stakeholders. The most efficient way for a country to enhance its power 
capabilities, therefore, was by combining the possibilities of hard power and soft power strategies.

Ultimately, Nye's core theory continued to adhere to the idea that states are able to consciously promote their influence.

\section{Deconstructing the rhetoric of soft power}

9 Such an approach blurs the lines between political discourse and objective observation. Presented as a scientific concept, soft power is also a term suited to coin the recommendations of foreign policy strategists. Nye's writings are clearly marked by a prescriptive tone, with regular in-text directives such as "the USA must" or "the USA will have to". This unclear position that the notion of soft power occupies between the academic and the political field is striking when we consider Joseph Nye's own multipositioning as a foreign policy advisor, an influential scholar at Harvard University, and the head of the North American group in the Trilateral Commission. As such, Nye emerges as an entrepreneur of globalisation, constituting a "transnational broker" (Dezalay 2004: 17) whose theoretical propositions are necessarily entailed in its own multi-positioned trajectory. As Dezalay shows, the continued dominance of the USA remains reliant on major investments in state knowledge, leading to the international diffusion of a form of government resulting from a specific history. The field of knowledge appears to be intimately entangled in the field of power, and concepts such as "soft power" can thus be viewed as instruments of American hegemony (Ibid.). Consequently, as far as soft power's use in an academic context is concerned, this blurry borderline between category of practice and category of analysis raises questions (Brubaker and Cooper 2006).

Thus, we can argue that soft power is less an analytical tool than an instrument of expertise for transnational brokers. As such, it competes with other concepts guiding practice, such as public diplomacy or nation branding, which are often used as alternatives to soft power. These terms carry slightly different meanings and are backed by different academic fields. Public diplomacy is a notion that pre-dates the emergence of soft power. Originating from the field of diplomacy, it is primarily a communication strategy for inducing policy change. As Malone (1985) argues, public diplomacy involves "direct communication with foreign peoples, with the aim of affecting their thinking and ultimately, that of their governments" (Ibid.: 199). Cultural diplomacy is a subcategory of public diplomacy, which Cull (2008) defines as a state's endeavour to promote and facilitate the international diffusion of its culture. Nation branding, however, is situated within a specific area of place branding and consists of applying marketing techniques to promote a nation (Fan 2006). In fact, the fields of use of these various terms reveal their differences. Like soft power, the notions of cultural diplomacy and nation branding tend to be mobilised by consultants who propose methods and best practices to help countries promote their influence (Schneider 2003; Anholt 2007).

11 Confronting these terms with soft power reveals its polysemy. Firstly, public diplomacy can be approached as a component of soft power, which emphasises the fundamental argument that a state possesses the ability to further its interests through conscious self-promotion. In many scholars' works, both terms are frequently used interchangeably. Secondly, soft power can be considered as a form of nation branding, 
underlying the fact that both concepts rely on the idea of attraction. Although it is a strategy, nation branding does not necessarily imply a state-led approach and calls for the further analysis of internal governance issues. Consequently, soft power appears as a "soft" or "uncertain concept" (Leca 2013) meaning that its strength mainly lies in how mouldable and polysemic it is. Hayden (2012) comments on the rhetoric of soft power to argue that it is based on a simple set of assumptions concerning the conditions of a country's power of persuasion, that has been circulated in a wide variety of countries, at a time when global communication became a key component of foreign policy.

\section{The international diffusion of the soft power concept}

12 The concept of soft power emerged in a specific historical, geographical, and political context, recalled by the opening sentence of Nye's Foreign Policy article: "The Cold War is over and Americans are trying to understand their place in a world without a defining Soviet threat" (Nye 1990b: 153). The notion enjoyed widespread success among policy-makers, rapidly going on to become a commonly used expression denoting the alternative tools available to a state for the development of its influence. For instance, a Canadian defence ministry official proposed a synthesis of the concept of soft power arguing that it could represent an alternative or complementary means to military power (Smith-Windsor 2000). Similarly, Cooper, an official at the European Council, referenced several historical cases ranging from the Pope's influence to the Warsaw pact to conclude that "Hard power and soft power are two sides of the same coin" (Cooper 2004: 15), namely that through different means, states pursue the same goals.

13 An analysis of the publications using the keyword "soft power" reveals that its use has extended beyond the initial geographic context of its emergence. Worldwide, scholars have mobilised the term to analyse a wide range of countries: China (Cho and Jeong 2008; Wang 2008; Bates and Huang 2009; Paradise 2009; Kurlantzick 2007), Russia (Popescu 2006; Tsygankov 2006), Japan (Lam 2007; Otmazgin 2008), Brazil (Lee et al. 2010; Lee and Gomez 2011), India (Malone 2011; Hymans 2009; Thussu 2013), Korea (Hayashi and Lee 2007; Lee 2009). The appropriation of soft power theory across multiple and diverse contexts extended the scope of the concept beyond the immediate concerns of post-Cold War American power to encompass the rising influence of emerging countries. As it was applied to these different contexts, the meanings and lines of debate correspondingly shifted. In the case of China, for example, American scholars such as Vogel (2006) have argued that the country's power of attraction is derived from its display of a lack of will to link the development of economic cooperation to the spread of its values, which is the exact opposite of what constitutes American soft power according to Nye.

These works tend to draw on the stereotypical components of a country in order to consider their comparative powers of influence. While Nye portrays the USA as the embodiment of democracy and freedom, placing the emphasis on universities and involvement in international organisations, the application of the soft power concept to other country contexts focuses particularly on specific cultural interests such as the manga culture in Japan (Sugiura 2008), Bollywood in India (Thussu 2013), and the Confucius Institutes in China (Hartig 2012). 
Table: The diffusion and evolution of the soft power concept

\begin{tabular}{|l|l|l|}
\hline & Initial context & Subsequent adoption \\
\hline Historical frame & End of the Cold War & Information Age \\
\hline $\begin{array}{l}\text { Geographical } \\
\text { frame }\end{array}$ & USA and the world & $\begin{array}{l}\text { Emerging countries and their regions: China, } \\
\text { India, Brazil, Turkey etc. }\end{array}$ \\
\hline Political frame & $\begin{array}{l}\text { Idea of decline: Soft power as an } \\
\text { alternative asset }\end{array}$ & $\begin{array}{l}\text { Idea of rising regional influence: Soft power } \\
\text { as a complementary asset }\end{array}$ \\
\hline
\end{tabular}

Within this framework, Turkey, as an emerging power in international relations, has been the object of numerous studies centralizing the notion of soft power, authored both by scholars (Altınay 2008; Altunışık 2008; Oğuzlu 2007; Yörük and Vatikiotis 2013), and by policy experts (Kiriş̧̧i 2005; Çandar 2009; Kalın 2011). In the majority of these works, soft power tends to be used in a normative manner: it is regarded as the power of a democratised, economically open Turkey whose ability to combine Islam and democracy is regarded as an inspiration to Arab countries. It does not question the balances of power hidden behind this concept (Altunışık 2008). Furthermore, the term soft power is often used in a reductive way, for example, it has been presented merely as a synonym of "diplomacy" as opposed to "military power" (Çandar 2009). As Gourisse (2015) has shown, current literature on Turkish soft power can be broadly characterised - and criticised - for drawing on widely spread culturalist lines of debate. These academic productions propose to investigate the degree of compatibility between Islam and democracy or explain the difficulties of anchoring democratic values in the region (Halliday 1995; Çarkoğlu and Toprak 2000; Tessler and Altınoğlu 2004; Atasoy 2005; Arat 2007; Kanra 2009), and thus are situated in continuity with Bernard Lewis' analysis of Turkey's position as a unique Muslim democracy (Lewis 1994: 47-48).

Through the analysis of the genealogy, evolution, and appropriation of the concept of soft power, we have pointed out its limitations as an analytical tool. From the beginning, it has been embedded in the field of expertise and foreign policy strategy. The ready global acceptance and appropriation of the concept has been favoured by its digestibility and the ease of its applicability to any context. Yet, its international diffusion has also been the result of its use by various analysts, think tanks, consultants and experts located throughout the world. Two lines of critique can therefore be pointed out. Firstly, as the concept has been tailored to expertise and foreign policy strategy, and is prone to becoming a rhetorical discourse. As such it becomes analytically poor because it has to stretch to accommodate the needs of its recipients. Secondly, the analysis of where it comes from and how it spreads shows that it reflects a subjective worldview, which facilitates the emergence of stereotypical and prejudicial meanings. Therefore, the results of its successes paradoxically emerge as obstacles to bringing deeper analytical perspective.

The methodological and analytical consequences we could draw from these observations suggest that such uses of the concept of soft power tend to create shortcuts where the limits between concept and ideology become blurred, where the 
labelisation of the dynamic of soft power becomes a political stake, and where analysis, causes and effects, actors and vectors, scales and contexts, theoretical and empirical dimensions lose clarity. This led us to call for a critical appraisal of the concept, rather than taking its assumed value for granted.

\section{Challenging the soft power concept: An empirically grounded approach to Turkish influence}

18 Turkey, being at the forefront of the appropriation of soft power discourse, has provided a particularly relevant case study to challenge the concept. Therefore, the objective of this issue was to develop an empirically grounded body of research that started by taking a critical perspective on the concept of soft power as a stepping-stone for investigating the politics of Turkey beyond its borders. Indeed, our ambition was to characterise the different types and modalities of Turkey's influence to lead to the production of new and more adequate conceptual propositions for analysing Turkey's current situation. This endeavour gained the attention of scholars and provoked a diverse range of critical questions concerning policy evolution, the interaction between public and private actors, and the role of instruments and discourse in public policies.

\section{Contributions based on field researches}

19 This special issue has gathered together contributions rooted in different disciplines, including political science, sociology, and geography. It covers a wide variety of instruments and actors of Turkish influence, ranging from Turkish soap operas to the Gülen movement, from Kurdish businessmen to the Istanbul art world and emblematic sports events. They share a common grassroots analysis based on in-depth field researches with an emphasis on qualitative methods. The contributors investigated diverse geographic contexts such as Sub-Saharan Africa, North Africa, the Middle East, the Balkans, and East Asia. Through empirical researches, the different articles in this collection shed light on the concrete ways Turkey deploys itself beyond its borders.

Although the papers are all united by the common desire to depart from the theoretical and methodological constraints of a soft power approach, they do so from different perspectives. On one hand, some papers challenge the concept on an empirical level, by taking soft power as a discourse of Turkish policymaking, or by showing the limitations of the theoretical premises of soft power when applied to the Turkish case. On the other hand, after demonstrating the internal contradictions or inadequacies of the concept, other contributors have extended the argument to develop alternative theoretical frameworks informed by other conceptual approaches. Rather than accepting its presuppositions, the idea behind this issue was to deconstruct the theoretical reach of soft power, articulate its stakes, and evaluate its relevance to the case studies offered by the authors. Thus, despite the individual positions adopted in this special issue, the contributors highlight different sets of criticisms, which is hoped will fuel further academic debate on the topic. 


\section{A critical approach to the concept of soft power through the Turkish case-study}

21 Through their diverse undertakings of empirically grounded critical research, the contributors highlight the multiple weaknesses of the concept thereby providing a unique analytical perspective on soft power. Three core criticisms may be drawn from the recommendations and conclusions that were reached by the authors. Firstly, the papers extend beyond Nye's state-centered approach by investigating not only the complex interrelation between public and private actors, but also the dynamics of relations between international and domestic politics. Secondly, they criticise the mechanic and unidirectional approach that is derived from soft power, emphasising the importance of an interactionist perspective. Thirdly, they deconstruct the interests and power structures that lie behind soft power rhetoric, placing the emphasis on discourse analysis.

\section{Beyond a state-centered soft power. Opening the black box of Turkish foreign policy}

Firstly, the core principle of the concept of soft power is predominantly focused on the role of the state, which is considered the main actor and beneficiary of influence. This makes soft power dependent on the ability of the state to mobilise a diverse range of tools in order to expand its power on the international scene. Even if transnational actors are taken into consideration, the focus continues to remain on the state and its intended politics of influence. Soft power theory approaches the state as a homogeneous and coherent body. It does not take into consideration its divergent internal contradictory trends and voices (Hall 1993). This general criticism seems particularly relevant to our case study. Although the Turkish state is often described as strong and centralised, Aymes, Gourisse and Massicard (2015) have demonstrated that it lacks autonomy from the rest of the society, is characterised by its private appropriation by political parties, and remains permeable to partisan issues.

Furthermore, an analysis in terms of soft power tends to elude the complex relations that exists between state actors and private actors. Different types of interactions between private and public actors can be identified: collaborative, conflictual or discharged (Hibou 2004). Therefore, a study of the coalitions of actors with different agendas and fields of possibilities should be at the centre of any study on a country's devices of influence beyond its borders. In the case of Turkey, intermingled interactions between social elites and the state, the army and religious groups have been pointed out. These can result in private initiatives that go against the interests of the Turkish state. Reciprocally, struggles with private actors can lead Turkish diplomacy to act in contradictory ways to the interests of Turkey's influence (Angey 2015). In this conception, international space becomes a "political arena" of contestation and negotiation between groups competing to promote their own agendas while claiming the monopoly of the legitimate representation of Turkey beyond its borders. As Bourdieu has argued, "International struggles for domination [...] have their more certain foundation in the struggles within each national field, struggles within which the dominant definitions of the national, the foreign are themselves at stake, as weapons and as issues" (Bourdieu 2002: 8). Following Bourdieu, Dezalay (2004) 
shows the importance of the national field in the international positioning of transnational brokers. It relates to actors who become enrolled or instrumentalise themselves to negotiate their role in internal politics.

The internal stakes of "transnational brokers" have been clearly identified in Merve Özdemirkıran's article on the commercial activities developed by Kurdish businessmen from Turkey in Northern Iraq in order to reinforce their bargaining position within domestic politics. The ties that these businessmen previously fostered in the region became an asset after the Turkish Government started to develop its relations with the Kurdistan Regional Government. Likewise, Yohanan Benhaïm introduces the notion of the coproduction of foreign policy, involving both public and private actors. By investigating the changing modalities of the involvement of Gülen schools in Iraqi Kurdistan, the paper analyses the decline of the security paradigm in Turkish foreign policy in the course of the years after 2000. The paper rejects the claim that Gülen schools are the instigators of this policy shift, or even the conveyors of a soft power paradigm, to argue that rather they utilised the opportunity created by this shift to participate in the coproduction of Turkish foreign policy as part of a "complex web of reformists".

\section{From the unidirectional perspective of soft power to an interactionist approach}

Nye's theory relies on a mechanical chain of action. According to his theory, when a country adopts "soft" tools, it increases its attractiveness towards its foreign peers, which in turn enhances its power. This supposes that attraction can be converted into power. This special issue challenges the assumption of a mechanical link between culture and state power in two ways: First, by showing that an increase in a country's cultural influence may not necessarily translate into diplomatic outcomes; and secondly, by adopting an interactionist approach that takes into consideration the appropriation of a given message by its recipients.

On the one hand, Todd Hall's (2010) processual approach has underlined the difficulties in measuring attractiveness and securing with certainty a resulting increase in power; the fact that people wear jeans, Hall argues, does not lead them to endorse American foreign policies (Ibid.). Jana Jabbour's contribution in this issue demonstrates the limitations of the soft power model in the Turkish case. Her work on the exportation of Turkish soap operas to the Middle East suggests that in spite of the undeniable commercial success of the diffusion of Turkish shows, a correlative growth in political power cannot be automatically assumed. She shows that there is no systematic relation between the rate of consumption of television serials in Arab countries and the level of support towards Turkey's foreign policies, and significantly in terms of interstate negotiations. This refers back to differences in the intrinsic nature of these initiatives that tends to become obscured by soft power. Indeed, the convertibility of capital gathered in the cultural field into political capital remains dubious. If it does not translate into actual power, the very relevance of the notion of soft power can thus be questioned. The difficulties in assessing the impact of sport on the image or influence of a country is a comparative point made in Jean-François Polo's article on the concept of sports diplomacy, defined as the use of sport as a tool to serve diplomatic objectives, such as conveying a message, facilitating links prior to a policy shift, or cooling 
tensions. In the case of football matches held between Turkey and Armenia and Syria, the author shows how sport was employed as a strategic tool of Turkey's "zero problem with neighbours' policy". However, the paper suggests that sports diplomacy can only be effective when the political context is favourable to a warming of relations. This approach is therefore non-deterministic and alerts us to the analytical imperative of affording greater attention to the time frames in which these initiatives are implemented.

On the other hand, the soft power approach reveals a lack of interest in the reception of a country's initiatives in a foreign country. Yet, the sociology of reception in media studies has already approached the idea that a media message can be "decoded" and twisted in its use by its recipients (Hall 1973), and in a way that might contradict the intended project of the message's producers (Le Grignou 2003; Englund 2015). More generally, any initiative (cultural, political) can be re-appropriated by the recipients, which deploy "arts of doing"' (Certeau 1984) according to their own agendas. This anthropology of reception has been deepened, notably in the framework of development projects in Africa (Bierschenk et al. 2000).

In this perspective, any initiative instigated by a Turkish actor beyond its borders, whether public or private, should be studied through an interactive approach between the targeted individuals and the producers of the initiative. In this issue, Gabrielle Angey's work on the Gülen movement introduces an interactionist perspective. Departing from the widespread view that the development of Gülen schools in Africa signifies the success of Turkey's soft power, Angey investigated the trajectory of African students coming to Turkey after having studied in these schools. Her study reveals that conflicts can arise between the divergent agendas of African students and the quest for influence pursued by Turkish actors in the Gülen movement. Rather than increasing Turkey's attractiveness to the future African elite, who are represented as all but passive recipients, such conflicts conversely lead to sentiments of rejection.

\section{Beyond a culturalist perspective: Deconstructing the soft power discourse}

Finally, this special issue has contributed to the deconstruction of soft power discourse as emerging from a culturalist position that essentialises countries' values and culture. In Nye's (2011: 81) theory, "political values (when it lives up to them at home and abroad)" are considered as one of the three primary resources of soft power alongside culture and foreign policy. The USA would "by nature" be attached to democracy and human rights, and supposedly be "more universal" than other countries (for instance Japan or China in Nye 1990a, 2013). As a consequence, Nye tends to consider any policy contradicting this vision, such as Bush's invasion of Iraq in 2003, to be a demonstration of "hard power" and a subversion of American "real" values (Hall 2010). This infers a hierarchy: some countries are implicitly viewed as being essentially endowed with "more" universal values than others. This perceptual ordering requires reintegration into a reflective framework of analysis to link it to the field in which discursive knowledge productions on soft power is inserted. As Dezalay explains, the dominating position of the USA has been largely dependent on important investments in the field of state knowledge, which enabled the global diffusion of a particular form of government as the product of a specific history. The field of knowledge would thus be 
intimately interrelated with the field of power (Dezalay 2004: 17), and the production of concepts such as soft power would be situated as part of the hegemonising process of the USA. This vision appears all the more ethnocentric considering that Joseph Nye, an American thinker who believes in the leading role of the USA, advocates it. In order to depart from this culturalist view, several contributors to this issue analyse the context of production of soft power discourse.

Indeed, one way to avoid the trick of considering the "political values of Turkey" as culturally fixed is to focus on the discourses of soft power and analyse them as such. Previous scholarly analyses of the Turkish soft power have seldom questioned the political stakes related to the use of soft power discourse by think tanks or by political actors and the academic community. Kerem Öktem and Yohanan Benhaïm's contribution illustrates the political interests behind the "soft power label" in Turkey.7 They highlight the key role played by multi-positioned individuals in introducing soft power discourse to Turkey at the triadic junction of think tanks, academia and foreign policy. Öktem and Benhaïm's article demonstrates the geostrategic stakes behind the promotion of the Turkish soft power discourse as a proxy for America's power and image. In continuity with the construction of the idea of "Orient" by the West (Said 1978), soft power's academic productions and political discourses focusing on Turkey would consequently constitute a projection of the West on Turkey, either as a barrier or a peace keeper in the region. Ultimately, from a Saidian perspective we could argue that the soft power discourses concerning Turkey (both academic and expertise-driven, centered on Islam, secularism democracy, capitalism), would be more revealing of Western identity and fears than of Turkish reality.

Jérémie Molho's contribution deals with the performative effect of the construction of discourse. Through his analysis of the Istanbul art world as a complex system of actors comprising galleries, auction houses, art fairs and art institutions, Molho argues that strategies to develop international networks are based on beliefs constructed through processes of place-framing. The emphasis of key gatekeepers on the cultural proximity of contemporary cultural productions to the Middle East and the rise of Istanbul as an emerging regional cultural capital, for example, is considered by Molho to have encouraged the development of ties between the Istanbul art scene and neighbouring countries.

Furthermore, the theory of soft power implies cultural or political transfers moving from one territorial entity to another, each of them having their own set of cultural values, to another linked by specific sets of cultural values. This conception reduces the scope and stakes of the circulations of individuals, ideas, and "arts of doing". The inference of transferal simultaneously facilitates a temporal discrepancy between countries that "don't get [...] soft power" (Nye 2013), and countries that embody it and are considered global models in the course towards progress. This normative approach seems to imply that soft power corresponds to a higher level of development. Reactions towards the Gülen movement by African students in Istanbul studied by Gabrielle Angey, contest a uniform understanding of Turkey: the gap between the discourse on Turkey and the complex realities the students encounter is at the root of their discontent. Beyond the cultural transfer approach implied by soft power theory, this special issue has therefore tried to contribute to the analytical endeavour of undertaking a "trans-actings" approach: deconstructing the idea of blocks, focusing on the streams, the circulations, and examining what it produces 8 . 


\section{Concluding remarks} contributors of this issue have not only challenged its effectiveness, but unveiled the specific appropriations and unexpected consequences of the concept. The authors have thereby established the basis for further researches in International Relations and other fields. This issue calls for further critical inquiry into the stakes of the promotion of the notion of soft power, the interconnected power dynamics between public and private actors, and the circulations and blockings of its use. Without presupposing the existence of fixed cultural entities, this special issue encourages further studies on the articulation between international and domestic spaces. We hope this special issue of Beyond Soft Power: Stakes and configurations of the influence of contemporary Turkey will provide new insights into the complexity of Turkish influence and stimulate further debates. some possible research directions on concerns that we have been unable to cover in the scope of this issue or that warrant further investigation. international economic and cultural programs, such as TIKA [Türk İşbirliği ve Koordinasyon Ajansi] or Yunus Emre Institutes. An empirical analysis of such organisations could benefit from an understanding of the way in which national strategies of influence are implemented within organisations that are organically related to the Turkish state.

Secondly, approaches drawing on Gramsci's theory of cultural hegemony could help unpick the relations of power that exist between influence and coercion. Without treating it directly, the contributions to this issue brought us to question of hegemony': the absence of military action or paying-off does not necessarily entail the corresponding absence of coercion. While the soft power approach tends to separate sources of power, an approach in terms of hegemony brings coercion back into the equation (Bayart 2008). While the literature on "model" and "soft power" operates depoliticise the reality of power relations, the notion of hegemony inscribes it within an analysis of the global dynamics of domination..

37 Finally, following the sociology of the "transnational brokers" of the discourse on Turkish soft power discourse, introduced in Öktem and Benhaïm's discussion, could contribute to exposing the circulation of ideas and the internal stakes of the international positioning of intellectuals. Beyond the concept of soft power itself, the way for a better understanding of the role of the field of knowledge and expertise in the construction of the Turkish foreign policy could be opened up. 


\section{BIBLIOGRAPHY}

Altınay, Hakan (2008). “Turkey's Soft Power: An Unpolished Gem or an Elusive Mirage?,” Insight Turkey 10 (2), pp. 55-66. URL: http://file.insightturkey.com/Files/Pdf/ insight_turkey_vol_10_no_2_2008_altinay.pdf.

Altunışık, Meliha Benli (2008). “The Possibilities and Limits of Turkey's Soft Power in the Middle East,” Insight Turkey 10 (2), pp. 41-54. URL: http://file.insightturkey.com/Files/Pdf/ insight_turkey_vol_10_no_2_2008_altunisik.pdf.

Angey-Sentuc, Gabrielle (2015). « Le mouvement musulman turc de Fethullah Gülen en Afrique subsaharienne: faire l'école au transnational », Politique Africaine 139, pp. 23-42. DOI: 10.3917/ polaf.139.0023.

Anholt, Simon (2007). Competitive Identity. The New Brand Management for Nations, Cities and Regions, Basingstoke, Palgrave Macmillan. DOI: 10.1057/9780230627727.

Arat, Yeşim (2007). Rethinking Islam and Liberal Democracy: Islamist Women in Turkish Politics, New York, State University of New York Press.

Atasoy, Yıldız (2005). Turkey, Islamists and Democracy: Transition and Globalization in a Muslim State, London, I.B. Tauris.

Aymes, Marc; Gourisse, Benjamin; Massicard, Élise (2015). Order and Compromise. Government Compromise. Government Practices in Turkey from the Late Ottoman Empire to the Early $21^{\text {st }}$ Century, Leiden, Boston, Brill. DOI: 10.1163/9789004289857.

Balc1, B. (2014a). "What are the Consequences of the Split between Erdoğan and Gülen on Turkey's Foreign Policy?,” Foreign Policy Journal, 17 January 2014, URL: http://

www.foreignpolicyjournal.com/2014/01/17/what-are-the-consequences-of-the-split-betweenerdogan-and-gulen-on-turkeys-foreign-policy/.

Balc1, B. (2014b). "The Gülen Movement and Turkish Soft Power," Carnegie Endowment for International Peace, 4 February 2014, URL: http://carnegieendowment.org/2014/02/04/ g\%C3\%BClen-movement-and-turkish-soft-power.

Bates, Gill; Huang, Yanzhong (2006). “Sources and Limits of Chinese 'Soft Power', Survival 48 (2), pp. 17-36. DOI: 10.1080/00396330600765377.

Bayart, Jean-François (2004). Le gouvernement du monde. Une critique politique de la globalisation, Paris, Fayard.

Bayart, Jean-François (2008). « Hégémonie et coercition en Afrique subsaharienne. La politique de la chicotte », Politique africaine 110, pp. 123-152. DOI: 10.3917/polaf.110.0123.

Bierschenk, Thomas; Chauveau, Jean-Pierre; de Sardan, Jean-Pierre Olivier (eds.) (2000). Courtiers en développement: Les villages africains en quête de projets, Paris, Karthala. URL: http://

horizon.documentation.ird.fr/exl-doc/pleins_textes/pleins_textes_7/

b_fdi_03_05/010023423.pdf.

Bourdieu, Pierre (2002). « Les conditions sociales de la circulation internationale des idées », Actes de la recherche en sciences sociales 145, pp. 3-8. DOI: 10.3917/arss.145.0003.

Brubaker, Rogers; Cooper, Frederic (2000). “Beyond Identity," Theory and Society 29 (1), pp. 1-47. DOI: $10.1023 /$ A:1007068714468. 
Çandar, Cengiz (2009). “Turkey's Soft Power Strategy: A New Vision for a Multipolar World," SETA Policy Brief 38, pp. 3-11. URL: http://www.setav.org/Ups/dosya/34809.pdf.

Çarkoğlu, Ali; Toprak, Binnaz (2000). Değişen Türkiye'de din, toplum ve siyaset. Istanbul, TESEV yayınları. URL: http://tesev.org.tr/wp-content/uploads/2015/11/ Degisen_Turkiyede_Din_Toplum_Ve_Siyaset.pdf.

Certeau, Michel de (1984). The Practice of Everyday Life, trans. Steven Rendall, Berkeley, Los Angeles, University of California Press.

Cho, Young Nam; Jeong, Jong Ho (2008). “China's Soft Power: Discussions, Resources, and Prospects," Asian Survey 48 (3), pp. 453-472. DOI: 10.1525/as.2008.48.3.453.

Cooper, Robert (2004). "Hard power, soft power and the goals of diplomacy," in Held, David; Koenig-Archibugi, Mathias (eds), American Power in the $21^{\text {st }}$ Century, Cambridge-Malden, Polity, pp. 167-180. DOI: 10.1177/0002716207312618.

Cull, Nicholas J. (2008). "Public Diplomacy: Taxonomies and Histories, Public Diplomacy in a Changing World," in Annals of the American Academy of Political and Social Science 616, pp. 31-54. DOI: $10.1177 / 0002716207311952$.

Darbon, Dominique (dir.) (2009). La politique des modèles en Afrique. Simulation, Dépolitisation et appropriation, Paris, Karthala/MSHA.

Davutoğlu, Ahmet (2001). Stratejik Derinlik: Türkiye'nin Uluslararası Konumu, İstanbul, Küre Yayınları.

Dezalay, Yves (dir.) (2004). « Sociologie de la mondialisation. Héritiers, cosmopolites, mercenaires de l'impérialisme et missionnaires de l'universel » Actes de la recherche en sciences sociales 151/152. URL: https://www.cairn.info/revue-actes-de-la-recherche-en-sciences-sociales-2004-1.htm.

Englund, Harri (2015). Human Rights and African Airwaves: Mediating Equality on the Chichewa Radio, Bloomington and Indianapolis, Indiana University Press.

Fan, Ying (2006). “Branding the Nation: What is Being Branded?," Journal of Vacation Marketing 12 (1), pp. 5-14. DOI: 10.1177/1356766706056633.

Gourisse, Benjamin (2015). Projet Émergence(s) de la Mairie de Paris POLTUR « Espaces, réseaux et circulations. Les reconfigurations du politique en Turquie », unpublished.

Gramsci, Antonio (1971). Selections from the prison notebooks, New York, International Publishers.

Hall, Peter (1993). "Policy Paradigms, Social Learning, and the State. The Case of Economic Policymaking in Britain,” Comparative Politics 25 (3), pp. 275-296. DOI: 10.2307/422246.

Hall, Stuart (1973). “Encoding/Decoding in the Television Discourse," Paper for the Council of Europe Colloquy on "Training in the Critical Reading of Televisual Language", Birmingham Centre for Cultural Studies, University of Birmingham, in S. During (ed.), The Cultural Studies Reader, London, Routledge, pp. 507-517. URL: https://faculty.georgetown.edu/irvinem/theory/ SH-Encoding-Decoding.pdf.

Hall, Todd (2010). “An Unclear Attraction: A Critical Examination of Soft Power as an Analytical Category," The Chinese Journal of International Politics 3, pp. 189-211. DOI: 10.1093/cjip/poq005.

Halliday, Fred (1995). Islam and the Myth of Confrontation: Religion and Politics in the Middle East, London, I.B. Tauris.

Hartig, Falk (2012). "Confucius Institutes and the Rise of China," Journal of Chinese Political Science 17 (1), pp. 53-76. DOI: 10.1007/s11366-011-9178-7. 
Harvey, David (2003). The new imperialism. Oxford University Press, Oxford.

Hayden, Craig. (2012). The Rhetoric of Soft Power: Public Diplomacy in Global Contexts, Lanham, Boulder, New York, Lexington Books.

Hayashi, Kaori; Lee, Eun-Jeung (2007). "The Potential of Fandom and the Limits of Soft Power: Media Representations on the Popularity of a Korean Melodrama in Japan," Social Science Japan Journal 10 (2), pp. 197-216. DOI: 10.1093/ssjj/jym049.

Hibou, Béatrice (ed.) (2004). Privatizing the State, Paris, Columbia University Press/CERI.

Hymans, Jacques E.C. (2009). “India's Soft Power and Vulnerability,” India Review 8 (3), pp. 234-265. DOI: 10.1080/14736480903116784.

Kalın, Ibrahim (2011). “Soft Power and Public Diplomacy in Turkey," Perceptions: Journal of International Affairs 16, pp. 5-23. URL: http://sam.gov.tr/wp-content/uploads/2012/01/ ibrahim_kalin.pdf.

Kanra, Bora (2009). Islam, democracy and dialogue in Turkey: deliberating in divided societies, Farnham, Burlington, Ashgate.

Kirişçi, Kemal (2005). “A Friendlier Schengen Visa System as a Tool of 'Soft Power': The Experience of Turkey," European Journal of Migration and Law 7 (4), pp. 343-367. DOI: $10.1163 / 157181605776293219$.

Kurlantzick, J. (2007). Charm Offensive: How China's Soft Power Is Transforming the World, New Haven, London, Yale University Press.

Lam, Peng Er (2007). “Japan's Quest for 'Soft Power': Attraction and Limitation,” East Asia 24 (4), pp. 349-363. DOI: 10.1007/s12140-007-9028-6.

Leca, Jean (2013). « "Soft power". Sens et usages d'un concept incertain», CERISCOPE Puissance. URL: http://ceriscope.sciences-po.fr/puissance/content/part2/soft-power-sens-et-usages-d-unconcept-incertain.

Lee, Geun (2009). “A Theory of Soft Power and Korea's Soft Power Strategy,” The Korean Journal of Defense Analysis 21 (2), pp. 205-218. DOI: 10.1080/10163270902913962.

Lee, Kelley; Chagas, Luiz Carlos; Novotny, Thomas E. (2010). "Brazil and the Framework Convention on Tobacco Control: Global Health Diplomacy as Soft Power," PLoS Med 7 (4), e1000232. DOI: 10.1371/journal.pmed.1000232.

Lee, Kelley; Gomez, Eduardo (2011). “Brazil's Ascendance: The Soft Power Role of Global Health Diplomacy,” European Business Review January-February. URL: http://summit.sfu.ca/item/10866.

Le Grignou, Brigitte (2003). Du côté du public. Usages et réceptions de la télévision, [Études politiques 239], Paris, Économica.

Lewis, Bernard (1994). Cultures in Conflict. New York-Oxford, Oxford University Press.

Malone, David M. (2011). "Soft Power in Indian Foreign Policy," Economic and Political Weekly 46 (36), pp. 35-39. URL: http://www.epw.in/journal/2011/36/perspectives/soft-power-indianforeign-policy.html.

Malone, Gifford D. (1985). “Managing Public Diplomacy," Washington Quarterly 8 (3), pp. 199-210. DOI: $10.1080 / 01636608509450301$.

Nye, Joseph S. (1990a) Bound to Lead: The Changing Nature of American Power, New York, Basic Books. Nye, Joseph S. (1990b). “Soft Power,” Foreign Policy 80, pp. 153-171. DOI: 10.2307/1148580. 
Nye, Joseph S. (2004a). Power in the Global information Age: From Realism to Globalisation, London, Routledge.

Nye, Joseph S. (2004b). Soft Power: The Means to Success in World Politics. New York, Public Affairs.

Nye, Joseph S. (2005). "Soft Power and Higher Education," Forum for the Future of Higher Education (Archives), pp. 11-14. URL: https://net.educause.edu/ir/library/pdf/FFP0502S.pdf.

Nye, Joseph S. (2010). The future of power, New York, Public Affairs.

Nye, Joseph S. (2013). "What China and Russia Don't Get About Soft Power," Foreign Policy 29 URL: http://foreignpolicy.com/2013/04/29/what-china-and-russia-dont-get-about-soft-power/.

Nye, Joseph S. (April 5, 2015) "Joseph Nye says Turkey has less soft power, less democracy," Today's Zaman. URL: http://www.todayszaman.com/anasayfa_joseph-nye-says-turkey-has-lesssoft-power-less-democracy_377198.html.

Otmazgin, Nissim Kadosh (2008). “Contesting Soft Power: Japanese Popular Culture in East and Southeast Asia," International Relations of the Asia-Pacific 8 (1), pp. 73-101. DOI: 10.1093/irap/ lcm009.

Oğuzlu, Tarik (2007). “Soft Power in Turkish Foreign Policy,” Australian Journal of International Affairs 61 (1), pp. 81-97. DOI: 10.1080/10357710601142518.

Paradise, James F. (2009). "China and International Harmony: The role of Confucius Institutes in Bolstering Beijing's Soft Power,” Asian Survey 49 (4), pp. 647-669. DOI: 10.1525/as.2009.49.4.647.

Popescu, Nicu (2006). “Russia's soft power ambitions," CEPS Policy Briefs (1-12), pp. 1-3. URL: http://aei.pitt.edu/id/eprint/11715.

Said, Edward (1978). L'orientalisme, L'Orient créé par l'Occident, Paris, Points.

Sardan, Jean Pierre Olivier de (1993). «Le développement comme champ politique local », Bulletin de l'APAD 6. URL : http://apad.revues.org/2473.

Schneider, Cynthia P. (2003). "Diplomacy That Works: 'Best Practices'," Cultural Diplomacy Research Series, Washington DC, Center for Arts and Culture. URL: http:// www.americansforthearts.org/sites/default/files/Schneider.pdf.

Smith-Windsor, Brooke A. (2000). "Hard power, soft power reconsidered," Canadian Military Journal 1 (3) pp. 51-56. URL: http://www.journal.forces.gc.ca/vo1/no3/doc/50-56-eng.pdf.

Sugiura, Tsutomu (2008). “Japan's Creative Industries: Culture as a Source of Soft Power in the Industrial Sector," in McConnell, D.L.; Wanatabe, Y. (eds.) Soft Power: Superpowers - Cultural and National Assets of Japan and the United States, New York, M. E. Sharpe.

Tessler, Mark; Altınoğlu, Ebru (2004). "Political culture in Turkey: Connections among attitudes toward democracy, the military and Islam," Democratization 11 (1), pp. 21-50. DOI: 10.1080/13510340412331294122.

Thussu, Daya Kishan (2013). Communicating India's soft power: Buddha to Bollywood, Palgrave Macmillan. DOI: 10.1057/9781137027894.

Tsygankov, Andrei P. (2006). "If Not by Tanks, Then by Banks? The Role of Soft Power in Putin's Foreign Policy,” Europe-Asia Studies 58 (7), pp. 1079-1099. URL: http://www.jstor.org/stable/ 20451289.

Vogel, Ezra F. (2006). “The Rise of China's Soft Power," Belfer Centre for Science and International Affairs John F. Kennedy Jr. Public Forum, John F. Kennedy School of Government, Harvard University, 19 April 2006, URL: http://live.belfercenter.org/events/1005. 
Wang, Yiwei (2008). "Public diplomacy and the rise of Chinese soft power," The Annals of the American Academy of Political and Social Science 616 (1), pp. 257-273. DOI: 10.1177/0002716207312757.

Yörük, Zafer; Vatikiotis, Pantelis (2013). "Soft Power or Illusion of Hegemony: The Case of the Turkish Soap Opera 'Colonialism'," International Journal of Communication 7, pp. 2361-2385. URL: http://ijoc.org/index.php/ijoc/article/view/1880.

\section{NOTES}

1. The article was published in Today's Zaman, a newspaper close to the Gülen Movement, over a year after the Turkish Government began its crackdown on the Gülen movement. To read the article see, Nye (April 5, 2015).

2. The main initiators of the project include Gabrielle Angey, Yohanan Benhaïm, Élise Massicard, Jérémie Molho, Elshan Mustafayev and Julien Paris. The organisation of an international research workshop held at the French Institute of Anatolian Studies on 8 and 9 January 2014, formed the basis of this special issue.

3. The Gülen movement is a powerful Muslim movement in Turkey, particularly in the economic and the education fields. For further information concerning the conflict between the Turkish government and the Gülen Movement, see Balc1 (2014a, 2014b).

4. After the collapse of the Soviet Bloc, the perception of decline was due to the USA's diminishing share of world product and its excessively large commitment beyond its frontiers. See the introduction of Bound to Lead, op.cit.

5. Jean-Pierre Olivier de Sardan (1993: 13) defines an arena as the place "where strategic heterogeneous groups compete, moved by (material or symbolic) interests that are more or less compatible (où des groupes stratégiques hétérogènes s'affrontent, mûs par des intérêts (matériels ou symboliques) plus ou moins compatibles).

6. In the Practice of Everyday Life (1984), de Certeau argues that ordinary people can develop defensive tactics when subjects of a dominant organisation. This act of creative resistance is referred to as the arts of doing (arts de faire) and corresponds to routine activities such as walking or reading.

7. Parallel to this quickly evolving reality was "the rise and fall of soft power discourse" in Turkey at the junction of a triad involving think tanks, academics, and foreign policy actors. The main stages of these triadic productions are introduced in Yohanan Benhaïm and Kerem öktem's article.

8. Abstract from the ANR Project Trans-actings: « Penser par "transferts", disions-nous, revient à penser la mise en circulation comme étape subséquente à la production localisée de "cultures". Parler de "transfaire" c'est au contraire étudier ce qui est (re)produit par la circulation de savoirs et de pratiques. S'astreindre à comprendre des relations sans avoir préjugé de leurs termes ».

9. The idea of cultural hegemony was developed by Antonio Gramsci to argue that a state's domination is achieved through cohesion, active consent, and coercion (Gramsci 1971). Although it is thought of in terms of an internal purpose (the way in which a society holds together), it subsequently becomes used in external relations of power and is inserted into national frameworks (Said 1978; Bayart 2004, 2008). Therefore, it can be presented as an early and alternative theorisation of the soft power dynamic, but with the aim of denunciation. According to this approach, soft power would appear as a depoliticised, positively presented version of hegemony (Yörük and Vatikiotis 2013). On the other hand, cultural hegemony has been used to deconstruct the cultural dimension of domination. One can mention, for example, Harvey (2003: 41) on American imperialism: "The emulation of US consumerism, ways of life, cultural forms, 
and political and financial institutions has contributed to the process of endless capital accumulation globally." Finally, cultural hegemony starts with the same observations but draws opposite conclusions. It underlines the link between force and cultural tools contradicting its "soft" dimension by inserting it in imperialistic contexts (Said 1978).

\section{AUTHORS}

\section{GABRIELLE ANGEY-SENTUC}

PhD candidate EHESS (CETOBAC), Paris

French Institute of Anatolian Studies (IFEA), Istanbul angey.gabrielle@yahoo.com

JÉRÉMIE MOLHO

$\mathrm{PhD}$ candidate Angers University, France

jeremie.molho@gmail.com 